\title{
Glucosaminyl N-deacetylase in cultured fibroblasts: comparison of patients with and without diabetic nephropathy, and identification of a possible mechanism for diabetes-induced $\mathrm{N}$-deacetylase inhibition
}

\author{
A. Kofoed-Enevoldsen ${ }^{1}$, J.S.Petersen ${ }^{2}$, T. Deckert ${ }^{1}$ \\ ${ }^{1}$ Steno Diabetes Center, Gentofte, Denmark \\ ${ }^{2}$ Hagedorn Research Institute, Gentofte, Denmark
}

\begin{abstract}
Summary. Impaired heparan sulphate biosynthesis through diabetes-induced inhibition of glucosaminyl $\mathrm{N}$-deacetylase may have a central role in the development of diabetic nephropathy, and genetic differences in the vulnerability of the $\mathrm{N}$-deacetylase could influence the risk of developing nephropathy. We studied $\mathrm{N}$-deacetylase activity in fibroblast cultures from Type 1 (insulin-dependent) diabetic patients with ( $n=14)$ or without $(n=13)$ diabetic nephropathy, together with non-diabetic control subjects $(n=7)$. No difference in $\mathrm{N}$-deacetylase activity was found $(p=0.13)$, and no inhibition of $\mathrm{N}$-deacetylase was found in cultures grown at $25 \mathrm{mmol} / 1$ glucose. $\mathrm{N}$-deacetylase activity was inversely correlated to growth rate $(r=-0.59, p=0.0008)$, and in patients with nephropathy a negative correlation between $\mathrm{HbA}_{1 \mathrm{c}}$ and fibroblast $\mathrm{N}$-deacetylase activity $(r=-0.72$, $p=0.012$ ) was found. Cell-cycle analysis revealed an increased fraction of S-phase cells in patients with nephropathy (28\% (21-52\%)) compared to healthy control subjects (17\%
\end{abstract}

$(9-24 \%)), p=0.0008$, but not between patients with and without nephropathy (latter group $26 \%(11-43 \%)$ ), $p=0.43$. Forskolin, an activator of protein kinase A, specifically decreased $\mathrm{N}$-deacetylase activity, whereas activation of protein kinase Cproduced a combined reduction in N-deacetylase activity and total protein synthesis. In conclusion, no constitutive defects in $\mathrm{N}$-deacetylase activity were found in fibroblasts from these patients. Further studies should consider possible associations between fibroblast characteristics and pre-biopsy environmental parameters related to cellular memory phenomena. Finally, activation of protein kinase A provides a potential general pathway for regulating $\mathrm{N}$-deacetylase activity.

Key words: Diabetic nephropathy, heparan sulphate, genetic predisposition, fibroblast, cell culture, growth rate, cellcycle, protein kinase A, protein kinase $\mathrm{C}$.
A genetic factor seems to influence the individual risk of developing diabetic nephropathy in Type 1 (insulin-dependent) diabetic patients [1]. Identification of this factor is however hampered by our current lack of knowledge concerning the pathogenesis of diabetic nephropathy.

A potentially central pathogenetic element is the impairment of heparan sulphate proteoglycan metabolism [2-5]. As a widespread extracellular component, the functional roles of heparan sulphate include maintenance of glomerular charge selectivity [6,7], endothelial anticoagulant function and lipid metabolism [8], and regulation of cellular growth [9]. Reduced sulphation of the heparan sulphate glycosaminoglycan chains, which may lead to impairment of any of these functions, has been demonstrated in experimental diabetes $[10,11]$. The sulphation of heparan sulphate takes place in the Golgi apparatus, initially under the control of the enzyme glucosaminyl Ndeacetylase (EC no. 3.5.1.33) [12]. The activity of this enzyme is markedly inhibited in experimental diabetes
$[13,14]$. Furthermore, evidence of genetically determined differences in the vulnerability of the $\mathrm{N}$-deacetylase has been found in closely-related rat strains [15]. This combination of (i) key role in heparan sulphate synthesis, (ii) diabetes-induced inhibition, and (iii) genetically-determined. vulnerability, indicates that $\mathrm{N}$-deacetylase is a major candidate to be a genetically controlled risk factor.

The impact of genetic factors on cellular biology may be studied using individual cell cultures. Thus, skin fibroblast cultures from patients with diabetic nephropathy have recently been found to express abnormalities in heparan sulphate biosynthesis as well as in regulation of growth and intracellular $\mathrm{pH}$ [16-18]. We have therefore studied $\mathrm{N}$-deacetylase activity in skin fibroblast cultures from diabetic patients, hypothesizing that reduced activity, or related abnormalities in the regulation of the activity when exposed to diabetes-associated environmental factors, would be found in cultures from patients with diabetic nephropathy. The fibroblast cultures were exposed to high or 
Table 1. Study population

\begin{tabular}{llll}
\hline & $\begin{array}{l}\text { Control } \\
\text { subjects }\end{array}$ & D1 & D2 \\
\hline$n /($ male $)$ & $7 /(5)$ & $13 /(7)$ & $14 /(8)$ \\
Age (years) & $33(28-34)$ & $40(29-48)$ & $39(32-53)$ \\
$\begin{array}{l}\text { Diabetes duration (years) } \\
\text { HbA } 1 \text { ( } \%)\end{array}$ & - & $25(12-44)$ & $25(16-38)$ \\
$\begin{array}{l}\text { Anti-hypertensive } \\
\text { treatment }(n)\end{array}$ & 0 & $8.4(6.3-10)$ & $9.2(8.2-11.1)$ \\
$\begin{array}{l}\text { Retinopathy } \\
\text { (None/background/ } \\
\text { proliferative) }\end{array}$ & - & 0 & 14 \\
\hline
\end{tabular}

Data are median (range) or counts. D1, Diabetic patients with normal urinary albumin excretion; D2, diabetic patients with overt diabetic nephropathy

Table 2. Cell growth rate as determined by cell count and by cellcycle analysis

\begin{tabular}{lllll}
\hline & $\begin{array}{l}\text { Control } \\
\text { subjects }\end{array}$ & D1 & D2 & $p$-value \\
\hline $\begin{array}{l}\text { Growth rate } \\
\text { (\% per day) }\end{array}$ & $22(8-50)$ & $33(11-51)$ & $24(-7-51)$ & 0.56 \\
$\begin{array}{llll}\text { G1-phase } \\
\text { ( } \%)\end{array}$ & $68(58-79)$ & $59(34-79)$ & $52(41-71)$ & 0.039 \\
$\begin{array}{l}\text { S-phase } \\
\text { ( } \%)\end{array}$ & $17(9-24)$ & $26(11-43)$ & $28(21-52)$ & 0.007 \\
$\begin{array}{l}\text { G2 }+ \text { M- } \\
\text { phase }^{c}(\%)\end{array}$ & $17(13-19)$ & $16(8-23)$ & $14(6-24)$ & 0.82 \\
\hline
\end{tabular}

${ }^{a}$ By Kruskall Wallis test. Between the groups, significant differences (Mann Whitney test) in G1- and S-phase fractions were found between C and D2 ( $p=0.006$ and $p=0.0008, \mathrm{G} 1$ - and S-phase, respectively), but not between C and D1 ( $p=0.20$ and $p=0.09)$ or between D1 and D2 $(p=0.50$ and $p=0.43) .{ }^{\mathrm{b}}$ Based on cell counting 3 days after plating. ${ }^{\complement}$ Flow cytometric analysis of DNA content was performed as described in Subjects, materials and methods, and the fraction of cells in G1, S, and M + G2-phase calculated. D1, Diabetic patients with normal urinary albumin excretion; D2, diabetic patients with overt diabetic nephropathy

to normal glucose concentration. In addition, since activation of protein kinase A or C may be partly responsible for the abnormal basement membrane metabolism in diabetic angiopathy [19], the effect of protein kinase A or C activation on $\mathrm{N}$-deacetylase activity was tested.

\section{Subjects, materials and methods}

Study population: Twenty-seven Type 1 diabetic patients and seven healthy subjects participated in the study. The diabetic patients had either normal urinary albumin excretion (less than $30 \mathrm{mg} / 24 \mathrm{~h}$, $n=13$, group D1) or overt diabetic nephropathy (albumin excretion above $300 \mathrm{mg} / 24 \mathrm{~h}$ without other known cause than diabetic nephropathy, $n=14$, group D2). Patients in group D2 had a median serum creatinine of $99 \mu \mathrm{mol} / 1$ (range 77 to 135 ), and had developed persistent proteinuria within 15 (11 to 32 ) years of diabetes duration. Further clinical characteristics are given in Table 1 . The study was approved by the local ethical committee and informed consent obtained from all participants.

Culture conditions: Primary skin fibroblast cultures were established from skin punch biopsies $(4 \times 4 \mathrm{~mm})$ taken from the deltoid region. Cells were grown in Minimal Essential Medium-Eagle (all reagents purchased from Gibco, Roskilde, Denmark, unless otherwise stated) with $15 \%$ fetal calf serum, $2 \mathrm{mmol} / \mathrm{l} \mathrm{L}$-glutamine, $200 \mathrm{IU} / \mathrm{ml}$ penicillin and $200 \mu \mathrm{g} / 1$ streptomycin. All cultures were grown at $5 \mathrm{mmol} / \mathrm{l}$ glucose, the medium was changed three times per week, and cultures were split (ratio 1:2) when confluent. The experiments were performed after 6 to 10 passages. Seven days before the final harvest, parallel cultures were grown (split 1: 2 once after 4 days) in medium supplemented with $25 \mathrm{mmol} / 1$ or $5 \mathrm{mmol} / 1$ glucose. Culturing and experiments were performed by a technician who was unaware of the patients identity.

Growth rate: Individual growth rates were measured by cell counting and by cell-cycle analysis. Cells $\left(2 \cdot 10^{5}\right)$ from confluent cultures, were platedin a $80 \mathrm{~cm}^{2}$ culture flask with $20 \mathrm{ml}$ medium. After $72 \mathrm{~h}$ the cells were harvested, counted under the microscope using a Bürker-Türck counting chamber, and stored at $-20^{\circ} \mathrm{C}$ until cell-cycle analysis was performed. After thawing, cells were stained with $500 \mu \mathrm{l}$ of lysisDNA-solution [20] consisting of calcium and magnesium free Dulbecco's phosphate buffered saline $\left(0.2 \mathrm{~g} / 1 \mathrm{KCl}, 0.2 \mathrm{~g} / 1, \mathrm{KH}_{2} \mathrm{PO}_{4}, 8 \mathrm{~g} / 1\right.$ $\left.\mathrm{NaCl}, 2.16 \mathrm{~g} / \mathrm{Na}_{2} \mathrm{HPO}_{4} \cdot 7 \mathrm{H}_{2} \mathrm{O}\right), 0.5 \%$ volume/volume Nonidet $\mathrm{P}-40$, $20 \mu \mathrm{g} / \mathrm{ml}$ propidium iodide (Sigma, St. Louis, Mo., USA) $0.2 \mathrm{mg} / \mathrm{ml}$ RNase (R-5503, Sigma), and $0.5 \mathrm{mmol} / 1 \mathrm{EDTA}$ at $\mathrm{pH} 7.2$ for $30 \mathrm{~min}$ at $4^{\circ} \mathrm{C}$. The propidium iodide fluorescence (linear scale) was then measured in a FACScan flow cytometer (Becton Dickinson, Glostrup, Denmark), with a flow rate of $100-500$ counts per second, using the program Cell Fit, sum of broadened rectangles.

$N$-deacetylase measurements: Confluent cultures were washed twice in Hanks' balanced salt solution (HBSS) $(0.4 \mathrm{~g} / \mathrm{l} \mathrm{KCl}, 0.06 \mathrm{~g} / \mathrm{l}$ $\mathrm{KH}_{2} \mathrm{PO}_{4}, 8 \mathrm{~g} / \mathrm{l} \mathrm{NaCl}, 0.09 \mathrm{~g} / \mathrm{l} \mathrm{Na} \mathrm{HPO}_{4} \cdot 7 \mathrm{H}_{2} \mathrm{O}, 1 \mathrm{~g} / \mathrm{l}$ D-glucose) and harvested by scraping. The cell pellet was suspended in $300 \mu \mathrm{l}$ hypotonic detergent buffer $(0.05 \mathrm{~mol} / \mathrm{l}$ Tris, $1 \%$ Triton-X-100, $2 \mathrm{mmol} / 1$ EDTA) for $10 \mathrm{~min}$ at room temperature. Protein concentration in the microsomal fraction (i.e. the supernatant after centrifugation at $12,000 \mathrm{~g}$ for $2 \mathrm{~min}$ ) was assayed with the bicinchoninic acid protein assay reagent (Pierce, Rockford, III., USA) on a Cobas Mira (Roche, Hvidovre, Denmark) automated analyser, using human reference serum (Orion Diagnostics, Espoo, Finland) as the standard. Total microsomal protein $(25 \mu \mathrm{g})$ was used for $\mathrm{N}$-deacetylase activity measurement, according to the method of Navia et al. [21], with a $50,000 \mathrm{kDa} \mathrm{N}-\left[{ }^{3} \mathrm{H}\right]$-acetyl-labelled Escherichia coli $\mathrm{K} 5$ capsular polysaccheride $(5 \mathrm{mg} / \mathrm{l})$ as the substrate [14]. The assay was performed as previously described [15]. Within and between assay coefficients of variation were below $5 \%$ and $10 \%$ respectively. Results are expressed as cpm $\cdot 25 \mu \mathrm{g}$ total protein ${ }^{-1} \cdot 30 \mathrm{~min}^{-1}$.

Effect of protein kinase $A$ or $C$ activation on $N$-deacetylase activity: Confluent cultures from healthy control subjects were incubated for $18 \mathrm{~h}$ with $100 \mu \mathrm{mol} / \mathrm{l}$ forskolin (Sigma, F-6886) or 0.08 to $50 \mu \mathrm{g} / 1$ phorbol-12,13-dibutyrate (PDBU) (Sigma, P-1269). The effect of short-term PDBU $(50 \mu \mathrm{g} / \mathrm{l})$ incubation on $\mathrm{N}$-deacetylase activity was measured after $0.5,1,2,4,8$, and $60 \mathrm{~min}$. Forskolin stimulates adenylatcyclase leading to increased cAMP formation and protein kinase $\mathrm{A}$ activation, while PDBU activates protein kinase $\mathrm{C}$ by mimicking the effect of diacylglycerol.

Total protein synthesis: To evaluate the specificity of the effect of protein kinase $\mathrm{A}$ or $\mathrm{C}$ activation on $\mathrm{N}$-deacetylase activity, the effect of forskolin or PDBU on total protein synthesis rate was measured. Cultures in $7 \mathrm{~cm}^{2}$ dishes were incubated with $1 \mu \mathrm{Ci}{ }^{3} \mathrm{H}$-labelled leucine (L-[4, 5- $\left.{ }^{3} \mathrm{H}\right]$-leucine; Amersham Int., Amersham, Bucks., UK) in leucine-free Eagles medium MEM with $1 \%$ fetal calf serum, following $18 \mathrm{~h}$ of incubation with forskolin or PDBU as described above. After $1 \mathrm{~h}$, cells were washed four times with ice-cold HBSS and subsequently lysed by adding $1 \mathrm{mi} 0.1 \%$ SDS and leaving them to stand for $30 \mathrm{~min}$ at $37^{\circ} \mathrm{C}$. Protein was precipitated by adding $0.1 \mathrm{ml} 100 \%$ trichloroacetic acid and the sample left at $4^{\circ} \mathrm{C}$ for $4 \mathrm{~h}$. The precipitated protein was captured on a BetaPlate filter mate $\mathrm{A}$ (Pharmacia, Uppsala, Sweden) using a suction device (Skatron, Lier, Norway), washed twice in $2.5 \mathrm{ml} 4 \%$ trichloroacetic acid, and ${ }^{3} \mathrm{H}$ incorporation counted in a LKB BetaPlate scintillation counter. 


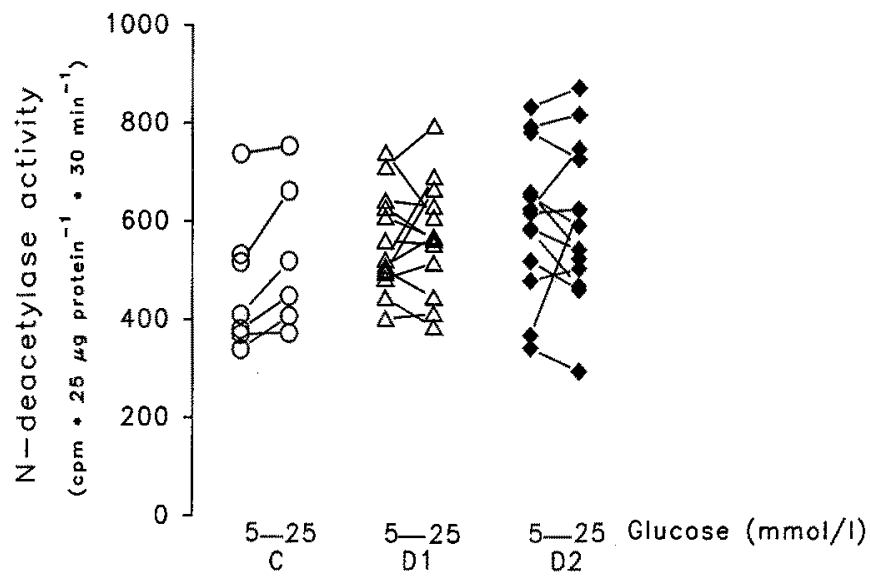

Fig.1. N-deacetylase activity in primary skin fibroblast cultures from healthy control subjects (C), diabetic patients with normal urinary albumin excretion (D1), and diabetic patients with overt diabetic nephropathy (D2). Cells were cultured under normal $(5 \mathrm{mmol} / \mathrm{l})$ and high $(25 \mathrm{mmol} / \mathrm{l})$ glucose conditions. High glucose conditions induced a significant increase in $\mathrm{N}$-deacetylase activity in healthy control subjects $(p=0.04)$. The groups were otherwise not significantly different $(p=0.13)$

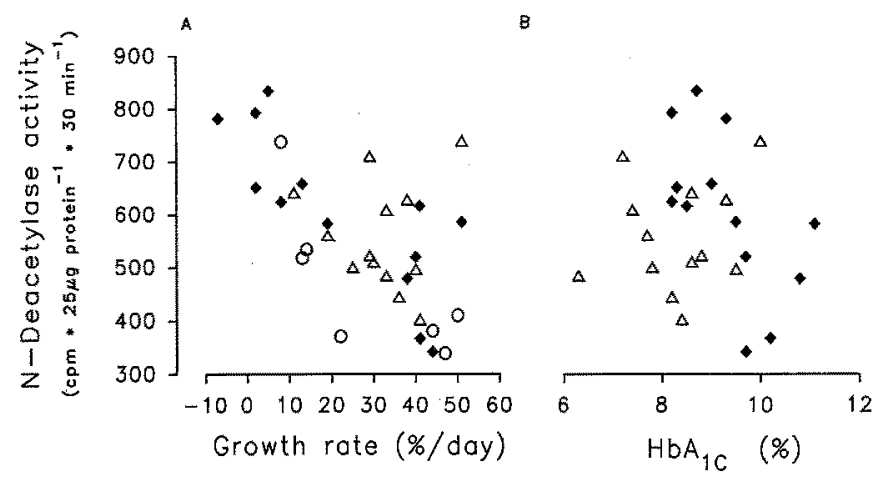

Fig. $2 \mathrm{~A}, \mathbf{B}$. Correlations between $\mathrm{N}$-deacetylase activity, cell growth rate, and $\mathrm{HbA}_{1 \mathrm{C}}$ in primary skin fibroblast cultures from healthy control subjects $(O)$, diabetic patients with normal urinary albumin excretion $(\Delta)$, and diabetic patients with overt diabetic nephropathy $(\bullet)$. A: Cell growth rate was calculated from cell counting following $72 \mathrm{~h}$ growth of $2 \cdot 10^{5} \mathrm{skin}$ fibroblasts plated in a $7 \mathrm{~cm}^{2} \mathrm{cul}-$ ture dish. A negative correlation between cell growth rate and $\mathrm{N}$ deacetylase activity was found $(r=-0.59, p=0.0008)$. B: $\mathrm{HbA}_{10}$ was measured in the diabetic patients at the time of the skin biopsy, after which cells were cultured for 2 to 3 months under standardised in vitro conditions. A negative correlation between $\mathrm{HbA}_{1 \mathrm{C}}$ and $\mathrm{N}$ deacetylase activity was found in patients with overt nephropathy $(r=-0.72, p=0.01)$ but not in patients with normal albumin excretion $(\mathrm{r}=0.19, p=0.51)$

\section{Statistical analysis}

Non-parametric tests (Wilcoxon's signed rank sum test, Mann-Whitney rank sum test, Kruskall Wallis one-way analysis by rank, and Spearman rank correlation) were used. Two-tailed $p$-values below 0.05 were considered significant. Results are presented as median(range) unless otherwise stated.

\section{Results}

$\mathrm{N}$-deacetylase activity in the skin fibroblast cultures grown at $5 \mathrm{mmol} / \mathrm{l}$ glucose did not differ between the groups $(p=0.13)$, and no general effect on $\mathrm{N}$-deacetylase

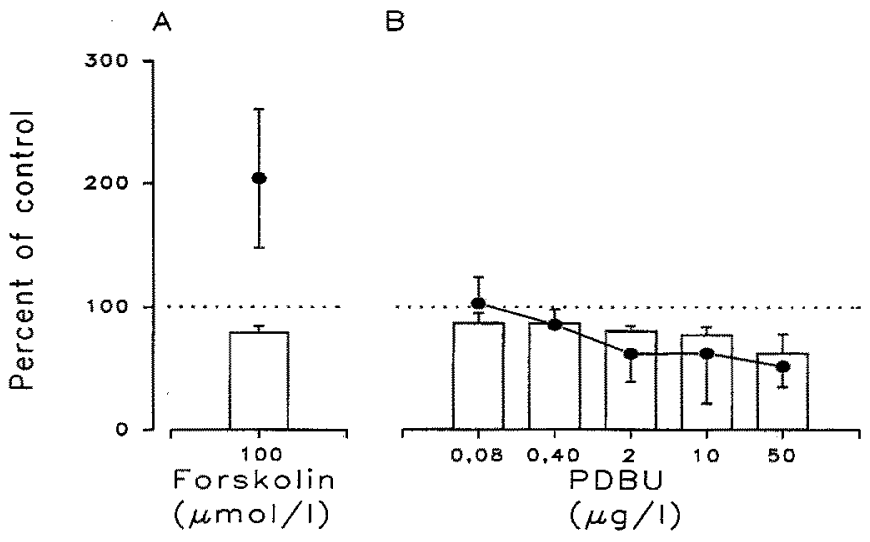

Fig.3A,B. Effect on N-deacetylase activity (bars) and total protein synthesis ( $)$ of $\mathbf{A}$ : protein kinase A activation (by $18 \mathrm{~h}$ incubation with $100 \mu \mathrm{mol} / 1$ forskolin) and $\mathbf{B}$ : protein kinase $\mathrm{C}$ activation (by $18 \mathrm{~h}$ incubation with 0.08 to $50 \mu \mathrm{g} / \mathrm{l}$ phorbol-12,13-dibutyrate (PDBU)) in primary skin fibroblast cultures from healthy control subjects $(n=4)$. Results are expressed as percent of individual parallel control cultures. Error bars indicate $95 \%$ confidence intervals

activity was found after culturing at $25 \mathrm{mmol} / \mathrm{l}$ glucose for 7 days (Fig. 1). In healthy control subjects however, cultures grown at $25 \mathrm{mmol} / \mathrm{l}$ glucose showed a minor increase in N-deacetylase activity from $410(339-737)$ to $484(372-$ 753 ),$p=0.04$ (Fig. 1)

There was no difference between the groups in growth rate as determined by cell counting (Table 2 ). The cultures reached $25 \%(7-77 \%)$ of their confluent density during the $72 \mathrm{~h}$ of the growth rate experiment (C: $23 \%(14-38 \%$ ); D1: $45 \%(8-77 \%)$; D2: $25 \%(7-68 \%))$. In contrast, the fraction of cells in the S-phase after $72 \mathrm{~h}$ was significantly increased in group D2 compared to group $\mathrm{C}(p=0.0008)$, whereas group $\mathrm{D} 1$ did not differ from either $\mathrm{C}(p=0.09)$ or $\mathrm{D} 2(p=0.43)$, Table 2 .

Similar results were obtained, when only D1 patients with a diabetes duration above 25 years $(n=7)$ and group D2 patients with onset of diabetic nephropathy before 15 years of diabetes duration $(n=8)$ were included in the analysis, (not shown).

$\mathrm{N}$-deacetylase activity in cultures grown at $5 \mathrm{mmol} / \mathrm{l}$ glucose correlated positively to age $(\mathrm{r}=0.43, p=0.016)$ and negatively to growth rate $(r=-0.59, p=0.0008)$ (Fig. 2a). Interestingly, there was a relatively strong negative correlation between $\mathrm{HbA}_{1 \mathrm{C}}$ and $\mathrm{N}$-deacetylase activity in patients from D2 $(r=-0.72, p=0.012)$, but no such correlation within group D1 ( $\mathrm{r}=0.19, p=0.51)$ (Fig. 2b). Similar results were obtained in cultures grown at $25 \mathrm{mmol} / \mathrm{l}$ glucose (data not shown).

Overnight incubation with forskolin induced a $25 \%$ reduction in $\mathrm{N}$-deacetylase activity while increasing total protein synthesis rate almost two-fold (Fig. 3a). The amount of extractable protein per culture was not significantly increased by forskolin (mean \pm SD: $108 \pm 8 \%$ of control). PDBU induced a reduction both in $\mathrm{N}$-deacetylase activity and in total protein synthesis rate (Fig. 3b). No effect of short-term PDBU $(50 \mu \mathrm{g} / 1)$ incubation on $\mathrm{N}$-deacetylase activity was found (data not shown). 


\section{Discussion}

The study failed to demonstrate an inherited reduction in $\mathrm{N}$-deacetylase activity in skin fibroblast cultures from patients with diabetic nephropathy. High glucose had no general effect on $\mathrm{N}$-deacetylase activity, whereas stimulation of protein kinase A activity caused a specific reduction in N-deacetylase activity. This provides new insight into the mechanism of diabetes-induced $\mathrm{N}$-deacetylase inhibition, as well as information which can be used to determine the role of abnormal heparan sulphate metabolism in the development of diabetic nephropathy.

The lack of difference in N-deacetylase activity between the groups suggests that no major genetic defect leading to chronic widespread $\mathrm{N}$-deacetylase malfunction is present in patients developing diabetic nephropathy. Since high glucose failed to produce the diabetes-induced inhibition of $\mathrm{N}$-deacetylase activity previously found in vivo, the present study conditions may not expose potential differences in the vulnerability of the $\mathrm{N}$-deacetylase. Thus we cannot exclude a role for $\mathrm{N}$-deacetylase in the genetic predisposition to diabetic nephropathy. Two findings, (i) the effect of glucose on $\mathrm{N}$-deacetylase activity in control subjects and (ii) the correlation between $\mathrm{N}$-deacetylase activity and $\mathrm{HbA}_{1 \mathrm{C}}$ in patients from group $\mathrm{D} 2$, seems to challenge the fundamental presumption that skin fibroblast cultures grown in vitro for 2 to 3 months are devoid of previous in vivo environmental factors, e.g. diabetic metabolic control. Indeed, a memory phenomenon associated with high glucose in vitro has previously been described [22]. If skin fibroblasts from diabetic patients have been permanently marked by the antecedent in vivo metabolic state, the correlation between $\mathrm{N}$-deacetylase activity and $\mathrm{HbA}_{1 \mathrm{C}}$ in patients with diabetic nephropathy may indicate the presence of a regulatory response not found in patients without diabetic nephropathy. Further experimental support for this notion must be found before drawing any conclusions.

Increased intracellular $\mathrm{pH}, \mathrm{Na}^{+} / \mathrm{H}^{+}$antiport activity, and thymidine incorporation as recently reported suggests that skin fibroblast from patients with diabetic nephropathy may be characterized by an increased rate of proliferation $[17,18]$. This is of potential interest in relation to heparan sulphate metabolism. In agreement with the known growth-regulatory effects of heparan sulphate $[9,23]$, we found an inverse correlation between growth rate and $\mathrm{N}$-deacetylase activity. There was however no difference in growth rate, as calculated from cell counting, between our study groups. The cell-cycle analysis did indicate increased proliferative activity (at the time of harvest) in cultures from patients with nephropathy compared to healthy control subjects as also suggested by Trevisan et al. [18], but no difference was found between our diabetic patients with and without nephropathy. Thus, during standard culture conditions, no difference in the rate of proliferation between fibroblasts from patients with and without diabetic nephropathy was found. Under these conditions an increased rate of entrance into the Sphase may be linked to the diabetic state per se, perhaps related to a cellular memory phenomenon as discussed above. Clearly, the methodological differences between studies may expose different biological aspects, and future studies should continue to address abnormalities in growth rate related parameters between the patient groups.

Incubation with forskolin specifically reduced $\mathrm{N}$ deacetylase activity. We have previously found very rapid and complementary effects of insulin dose shifts on hepatic $\mathrm{N}$-deacetylase activity in streptozotocin-diabetic rats [24]. Insulin inhibits protein kinase A activity by decreasing the binding of cAMP to the enzyme [25,26]. Our study may therefore have identified a general pathway, i. e. protein kinase A activity, for regulation of $\mathrm{N}$-deacetylase activity. Insulin resistance may be associated with a decrease in insulin-induced protein kinase A down-regulation [26]. This could provide an explanation for the postulated association between development of diabetic nephropathy [27] and the presence of insulin resistance, involving decreased $\mathrm{N}$-deacetylase activity. The effect of protein kinase $\mathrm{C}$ activation as induced by PDBU on $\mathrm{N}$ deacetylase activity in our study seems related to a general toxic rather than a specific effect since total protein synthesis was down-regulated in parallel.

We conclude that whereas a role for $\mathrm{N}$-deacetylase in the development and genetic susceptibility to diabetic nephropathy may not be excluded by the present study, no major constitutive defects in $\mathrm{N}$-deacetylase activity is found in skin fibroblast cultures from patients with diabetic nephropathy. Further studies should consider possible associations between skin fibroblast culture characteristics and pre-biopsy clinical parameters such as $\mathrm{HbA}_{1 \mathrm{c}}$-related cellular memory phenomena. Finally, activation of protein kinase A provides a potential general pathway for regulation of $\mathrm{N}$-deacetylase activity.

Acknowledgements. Ms. J. Nielsen and Ms. K.Jensen are thanked for their excellent technical assistance. Dr. N.Billestrup is thanked for valuable discussion regarding the possible effect of protein kinase activation. The study was supported by a grant from Poul and Erna Sehested Hansen's Foundation.

\section{References}

1. Seaquist ER, Goetz F, Rich S, Barbosa J (1989) Familial clustering of diabetic kidney disease. N Engl J Med 320: 1161-1165

2. Shimomura H, Spiro RG (1987) Studies on macromolecular components of human glomerular basement membrane and alterations in diabetes. Diabetes 36: 374-381

3. Vernier RL, Steffes MW, Sisson-Ross S, Mauer SM (1992) Heparan sulfate proteoglycan in the glomerular basement membrane in type 1 diabetes mellitus. Kidney Int 41: 1070-1080

4. Kanwar YS, Rosenzweig LJ, Linker A, Jakubowski ML (1983) Decreased de novo synthesis of glomerular proteoglycans in diabetes. Proc Natl Acad Sci USA 80: 2272-2275

5. Deckert T, Feldt-Rasmussen B, Borch -Johnsen K. Jensen T, Kofoed-Enevoldsen A (1989) Albuminuria reflects widespread vascular damage. Diabetologia 32:219-226

6. Kanwar YS, Linker A, Farquhar MG (1980) Increased permeability of the glomerular basement membrane to ferritin after removal of glycosaminoglycans (heparan sulfate) by enzyme digestion. J Cell Biol 86: 688-693

7. Groggel GC, Stevenson J, Hovingh P, Linker A, Border WA (1988) Changes in heparan sulfate correlate with increased glomerular permeability. Kidney Int 33: 517-523 
8. Wight TN (1989) Cell biology of arterial proteoglycans. Atteriosclerosis 9: $1-20$

9. Groggel GC, Marinides GN, Hovingh P, Hammond E, Linker A (1990) Inhibition of rat mesangial cell growth by heparan sulfate. Am J Physiol 258:F259-F265

10. Kjellén L, Bielefeld D, Höök M (1983) Reduced sulfatation of liver heparan sulfate in experimentally diabetic rats. Diabetes 32 : 337-342

11. Cohen MP, Klepser H, Wu V-Y (1988) Undersulfation of glomerular basement membrane heparan sulfate in experimental diabetes and lack of correction with aldose reductase inhibition. Diabetes 37: 1324-1327

12. Lindahl U, Kusche M, Lidholt K, Oscarsson L-G (1989) Biosynthesis of heparin and heparan sulfate. Ann N Y Acad Sci 556: $36-50$

13. Unger E, Pettersson I, Eriksson UJ, Lindahl U, Kjellén L (1991) Decreased activity of the heparan sulfate modifying enzyme glucosaminyl $\mathrm{N}$-deacetylase in hepatocytes from streptozotocindiabetic rats. J Biol Chem 266: 8671-8674

14. Kofoed-Enevoldsen A, Eriksson UJ (1991) Inhibition of N-acetylheparosan deacetylase in diabetic rats. Diabetes 40: 1449 1452

15. Kofoed-Enevoldsen A (1992) Inhibition of glomerular glucosaminyl $\mathrm{N}$-deacetylase in diabetic rats. Kidney Int 41: 763-767

16. Deckert T, Horowitz IM, Kofoed-Enevoldsen A et al. (1991) Possible genetic defects in regulation of glycosaminoglycans in patients with diabetic nephropathy. Diabetes 40: 764-770

17. Davies JE, Ng LL, Kofoed-Enevoldsen A et al. (1992) Intracellular $\mathrm{pH}$ and $\mathrm{Na}^{+} / \mathrm{H}^{+}$antiport activity of cultured fibroblasts in diabetic nephropathy. Kidney Int 42: 1184-1190

18. Trevisan R, Li LK, Messent J et al. (1992) $\mathrm{Na}^{+} / \mathrm{H}^{+}$antiport activity and cell growth in cultured skin fibroblasts of IDDM patients with nephropathy. Diabetes 41:1239-1246

19. Cagliero E, Roth T, Roy S, Maiello M, Lorenzi M (1991) Expression of genes related to the extracellular matrix in human endothelial cells. J Biol Chem 266: 14244-14250

20. Larsen JK (1990) Washless double staining of a nuclear antigen (Ki-67 or bromodeoxyuridine) and DNA in unfixed nuclei. In:
Darynkiewicz Z, Crissman HA (eds); Methods in cell biology, flow cytometry, vol 33. Academic Press, NY, pp 227-234

21. Navia JL, Riesenfeld J, Vann WF, Lindahl U, Rodén L (1983) Assay of $\mathrm{N}$-acetyl heparosan deacetylase with a capsular polysaccharide from Escherichia coli K5 as substrate. Anal Biochem 135: $134-140$

22. Roy S, Sala R, Cagliero E, Lorenzi M (1990) Overexpression of fibronectin induced by diabetes or high glucose - phenomenon with a memory. Proc Natl Acad Sci USA 87:404-408

23. Edwards IJ, Wagner WD (1992) Cell surface heparan sulfate proteoglycan and chondroitin sulfate proteoglycan of arterial smooth muscle cells. Am J Pathol 140: 193-205

24. Kofoed-Enevoldsen A, Noonan D, Deckert T (1993) Diabetes induced inhibition of glucosaminyl N-deacetylase - effect of short-term blood glucose control. Diabetologia 36: 310-315

25. Walkenbach RJ, Hazen R, Larner J (1978) Reversible inhibition of cyclic AMP-dependent protein kinase by insulin. Mol Cell Biochem 19:31-41

26. Kida Y, Nyomba BL, Bogardus C, Mott DM (1991) Defective insulin response of cyclic adenosine monophosphate-dependent protein kinase in insulin resistant humans. J Clin Invest 87: 673679

27. Trevisan R, Nosadini R, Fioretto PA et al. (1992) Clustering of risk factors in hypertensive insulin-dependent diabetics with high sodium-lithium countertransport. Kidney Int 41: 855-861

Received: 14 December 1992

and in revised form: 10 February 1993

Dr. A. Kofoed-Enevoldsen

Steno Diabetes Center

Niels Steensens Vej 2

DK-2820 Gentofte

Denmark 